\title{
EU-UN partnership in military conflict management: Whither the African Union security infrastructure?
}

\author{
Alfredo Tjiurimo Hengari ${ }^{\star}$
}

\section{Abstract}

This article problematises the nascent relationship between the United Nations (UN) and the European Union (EU) in African conflict management. Constructing the EU as a security actor, including its validation through the $\mathrm{UN}$, is not a process solely based on the normative claims inherent in the EU as a sui generis actor, but more importantly such claims are grounded in the EU as offering greater capacity and efficiency in African conflict management. In light of this argument, many studies have analysed this relationship in terms of inputs and outputs in field missions undertaken under this framework. While the EU-UN relationship can be viewed a priori as a process driven by 'African needs and requirements' as an end security consumer, the development of the

* Alfredo Tjiurimo Hengari is a Ph.D.-fellow in political science and researcher at the Centre for Political Research at the University of Paris I Panthéon-Sorbonne. He was a guest researcher at the Dag Hammarskjöld Foundation in Uppsala from February to April 2011. 


\section{Alfredo Tjiurimo Hengari}

EU-UN relationship poses inherent risks to the African Union (AU) slogan of 'African problems, African solutions' or 'African solutions to African problems'.

In light of the above-mentioned, the EU-UN question is surprisingly un-problematised and has received little critical attention in this context. By putting the EU-UN relationship into focus, this article shifts attention to the increasing complexities and potential uncertainties that this type of institutionalisation and coordination can generate on the development of Africa's infrastructure and narratives of conflict management.

\section{Introduction}

The UN Charter has sufficient provisions in Chapter VIII (articles 52, 53 and 54) for meaningful collaboration and cooperation with regional organisations. Despite the stated aims of devolving responsibility to regional organisations in matters of peacekeeping operations, however, these provisions did not find concrete expression until after the end of the Cold War. The impasse was not only the result of great power rivalry, but, in part, also the consequence of differing interpretations regarding the primacy of the UN or regional organisations in the resolution of disputes. These differences had their roots in the then prevailing schools of thought preceding the founding of the UN after the collapse of the League of Nations. Two schools of thought were at the centre of this debate the United Kingdom (UK) expressed a view in favour of regional organisations becoming the bedrock of the post-war security infrastructure, while the United States (US) insisted on the primacy of the UN as the primary organisation in matters of peace and security. Views in Washington won the day when the US-inspired Durban Oaks proposals formed the basis of the San Francisco Conference in 1945. However, it was Latin America that argued in favour of regional security arrangements as a precondition for accepting the UN Charter (Jonah 2004). Notwithstanding the failures of the Organisation of African Unity (OAU) in African conflicts on the basis of the sovereignty norm, there is since the end of the cold war widespread acceptance for regional organisations to take leadership in solving conflicts. An important tabula rasa had been established 


\section{EU-UN partnership in military conflict management}

over the past two decades for regional organisations to coordinate meaningfully with the UN, as well as among each other.

After a retreat in the 1990s, there has over the past decade been a resurgence of the UN and various international actors, including the EU, the AU and African regional organisations, all of them playing increasing roles in peacekeeping activities in Africa (Bellamy et al. 2004:75-92). They have as such been advocating for a strong and institutionalised partnership that would give credence to the view of 'African problems, African solutions'. The UN and the EU have been insisting, at least at the level of rhetoric, on the complementarities of the twin approaches of subsidiarity and African ownership. What is however interesting to note is the silence of the Charter with regard to the responsibility of regional organisations when it comes to security outside their immediate geography. In African conflicts, this makes the EU an exception deserving a different take.

Ontologically the EU is an actor sui generis, and on that basis it is not formally a 'regional arrangement' in the sense of Chapter VIII of the Charter. However, its relationship with the $\mathrm{UN}$, oppositional and complementary, is more advanced than that of any organisation. This aspect makes the EU a unique conflict manager in the African environment.

This paper provides a short overview of the development of the current pattern of EU-UN cooperation and its institutionalisation in both the political and military realms. It argues that the involvement of the EU in African conflicts through the validation of the UN Security Council (UNSC) is not only a process driven by Franco-British requirements for conflict management in Africa, but one necessitated by Africa's own resurgent demands for security. The paper will provide a brief explanation for this argument by looking at the changing notions of security within Europe toward the end of the 1990s. Looking at crisis management on a continuum involving conflict prevention, peacekeeping and peacebuilding - combining military and civilian aspects of crisis management - it is argued that a more comprehensive and coherent approach, within both the UN and the EU, would allow for greater efficiency. The article problematises the EU-UN relationship in African conflicts as one that looks at Africa as a 


\section{Alfredo Tjiurimo Hengari}

liability and not necessarily an actor. Such a view potentially undermines the development of Africa's own conflict management and security infrastructure.

The study concludes with critical reflections concerning both the limits and opportunities of future EU-UN cooperation on the development of Africa's security infrastructure. Our reflections aim to encourage immediate and medium-term effects on structural changes in the political and institutional environment. While such changes may be difficult to achieve, their necessity is nonetheless argued for in this paper.

\section{Discourse on and institutionalisation of the EU-UN relationship}

Article 53 of the UN Charter (United Nations 1945) states:

The Security Council shall, where appropriate, utilize such regional arrangements or agencies for enforcement action under its authority. But no enforcement action shall be taken under regional arrangements or by regional agencies without the authorization of the Security Council, with the exception of measures against any enemy state, as defined in paragraph 2 of this Article, provided for pursuant to Article 107 or in regional arrangements directed against renewal of aggressive policy on the part of any such state, until such time as the Organization may, on request of the Governments concerned, be charged with the responsibility for preventing further aggression by such a state.

Inspired partly by the provisions of the UN Charter, the Amsterdam Treaty of the EU insists, among its five principal axes, on the strengthening of EU security as an objective of the European Security and Defence Policy (ESDP), which received a decisive boost at the Franco-British Summit at Saint Malo in December 1998. Even if some had considered Saint Malo as irrational since it goes against French and British preferences (Gégout 2002), it gave practical expression to the construction of common EU policies in African conflicts. While the initial 


\section{EU-UN partnership in military conflict management}

objective was to consolidate bilateral cooperation in Africa, Saint Malo had the unintended consequence of constructing a security identity for the EU.

The EU created, in line with this desired identity, security structures whose raison d'être was to respond to security threats. Such capacities had been validated by the international community, including African actors. The idea of closer cooperation with the UN had therefore become more urgent. After all, calls for closer and effective cooperation between regional organisations and the UN in conflict management were seen as in line with expressed goals of the Charter. However, such calls for closer cooperation do not imply the cooperation of the $\mathrm{UN}$ and regional organisations acting in concert toward solving conflicts in other parts of the world. Furthermore, such provisions are by definition vague, for a supranational organisation such as the EU. If various EU member states have contributed significantly to UN peacekeeping operations over the years, the relationship between the EU and the $\mathrm{UN}$ had been declaratory in nature and did not include military tools.

Nevertheless, in peace operations, with a new dimension assumed by the codification of the ESDP, the EU-UN relationship had witnessed important advances since 2000. The EU became, with the authorisation of the UNSC, a fully-fledged security actor in African conflicts. Important initiatives to cultivate a meaningful security relationship with the UN were only undertaken during the Swedish Presidency of the EU from January to June 2001. This new relationship, it was argued would be anchored in the mutualisation of approaches in conflict management, while ensuring that the EU would add value to the existing tools of the UN in the area. An exchange of letters between the Swedish Foreign Minister, Anna Lindh, and the UN Secretary-General, Kofi Annan, endorsed the following specific areas of focus and procedural plans for intensified interaction with the UN:

- Conflict prevention, in particular ensuring mutually reinforcing approaches.

- Civilian and military aspects of crisis management, in particular ensuring that EU's evolving military and civilian capacities provide real added value for the UN. 


\section{Alfredo Tjiurimo Hengari}

- The EU-UN dialogue will chiefly focus on the Western Balkans, the Middle East and Africa.

- The EU-UN dialogue will be strengthened through regular high-level meetings focusing on crisis management issues, and also through more frequent contacts at expert level (Permanent Mission of Sweden to the UN 2001).

The exchange of letters was further deepened by the EU Göteborg declaration in June 2001, which validated and laid out a framework for EU-UN cooperation in conflict management. The Göteborg Conclusions of the EU Council included that:

- Cooperation between the EU and the UN will be done on a case by case basis.

- The EU will not intervene automatically in crises.

- The EU will retain political control of the operations through its Security and Political Committee (Council of the European Union 2001).

If the EU remains willing to intervene in Africa under international law, these base principles provide the terms and limits. What deserves emphasis here is the insistence to maintain the monopoly of dealing with violence within Europe. Obtaining a UN mandate for ESDP operations does not appear to be a requirement as long as these operations are deployed in Europe with the consent of the host state, and are of a non-coercive or civilian nature. A few examples illustrate this trend. In Europe, the examples are the EU Police Mission in Bosnia and Herzegovina and Operations Concordia and Proxima in the Former Yugoslav Republic of Macedonia. These were not created by UNSC resolutions. Outside of Europe, the three civilian operations in Georgia (EUJUST THEMIS), Kinshasa (EUPOL KINSHASA), and Iraq (EUJUST LEX) provide other examples of such missions without UNSC resolutions.

In principle, such provision in the EU declaration goes against Chapter VIII, Article 53 of the UN Charter. This shows that the choice of the EU-UN cooperation could be explained through the normative and sociological legitimacy that the UN confers on states and organisations in matters of peace 
and security (Keohane 2006). However, it also shows that the EU seeks to carve out exceptions to the rule in line with its own interests.

Practice shows that the relationship between the EU and the UN is the consequence of a real need on the part of the UN to provide a substantive framework for solving African conflicts. But such a relationship also has important specificities. These specificities are not necessarily driven by African or UN requirements, but more by the spatial expectations of the EU. Such a view illustrates the complexity of the institutional framework. It is further accentuated through the absence of coherence with regard to initiating peace operations.

The debate about the EU-UN cooperation is as a consequence not just a simple debate about peace missions and the relationship of the UN with regional organisations in this issue area. It is far more complex as a result of the unique character of the EU (Ginsberg 2001; Soeterdorp 1999). In terms of the UN Charter, all matters relating to international peace and security are primarily the domains of action of the UN, most notably of the Security Council in which France and the UK are permanent members. If the EU has continued to underline the centrality of the UN in African conflicts, it has also used such platforms to carve out a place for itself in the African conflicts through the codification of an institutional relationship with the UN regarding Africa.

\section{From institutional codification to the African conflict terrain}

Following the first communication with regard to African conflicts in 1993, the EU launched its first military operation outside the European geographic space in 2003 in the form of Operation Artemis (Mace 2003) in the Democratic Republic of the Congo (DRC). This shows that since the formalisation of the EU-UN relationship in 2001, cooperation has gained in substance when the EU assumed operational responsibility in 2003 within the European perimeters. What is interesting to observe is that operations on the ground were followed by institutional deepening of the EU-UN relationship through joint declarations and statements, whose objective was to refine capabilities and capacities for effective conflict management in Africa. 


\section{Alfredo Tjiurimo Hengari}

It is interesting to note that the Artemis operation was carried out on the basis of an expressed request from the UN Secretary-General. But this was in the final analysis not much more than a request to France to lead an intervention in the name of the EU. Nevertheless, at an empirical level, the Artemis operation brought the institutionalisation of EU-UN cooperation many steps further, with the signature on 24 September 2003 of the 'Joint Declaration on UN-EU Cooperation in Crisis Management' by the UN Secretary-General and the EU presidency (Council of the European Union 2003). The declaration took note of the recent developments in EU-UN cooperation and identified four areas where further cooperation should be explored: planning, training, communication and best practices. A 'joint consultative mechanism', named Steering Committee, was established at working level to enhance coordination in these four areas and to follow through with the implementation of the Joint Declaration (Council of the European Union 2004).

2003 was thus defining for the role of the EU in African conflicts. These empirical advances accompanied by concrete field experiences of the Artemis type led to the redefinition and fine-tuning of the framework of cooperation in military crisis management. After the field experience of Artemis and several others, mostly in Europe, a joint conflict management exercise was held in 2005 under the code EST 05 in order to test the practical modalities of cooperation. Apart from the intergovernmental pillar leading cooperation in conflicts at the UN, the European Commission also released an important Communication on EU-UN relations offering in-depth analysis of the EU's general posture vis-à-vis the UN. In addition to calling for a renewed EU commitment to multilateralism, the Communication also put forward recommendations on how to maximise EU benefits in a wider EU-UN partnership, going far beyond traditional peacekeeping issues (European Commission 2003). Through these declarations and statements the EU has not only consolidated a position as an important interlocutor in African conflicts, but it has also potentially transformed the conflict management environment in Africa. This shows that there has been consistency on the part of the EU between the empirical, declaratory and normative frameworks of its relationship with the UN in Africa. 
There now exist regular meetings between officials of the EU and the SecretaryGeneral of the UN. In particular, the Under-Secretary-General of the Department of Peacekeeping Operations (DPKO) appears at least twice a year in Brussels in front of the Political and Security Committee of the EU. Such practices and interactions embedded over time transformed the context in which major states such as France and the UK react to African conflicts at the UN (Hengari 2006). Their interventions in the UNSC refer to EU positions and actions in matters of peace and security. To a certain degree, the EU-UN cooperation not only has an impact on relations between the two actors, but also has a broader impact on other states being socialised into the $\mathrm{EU}-\mathrm{a}$ desirable situation for resolving African conflicts.

\section{The hierarchical framing of Africa as a problem deserving EU-UN coordination}

The EU has taken important steps in the African conflict management environment since 1993. If the initial communication was merely at the level of a statement on African conflicts, the EU had become a fully-fledged conflict management actor, deploying both civilian and military aspects in African conflicts. Rosemary Foot, Michael Mastanduno and S. Neil MacFarlane (2003) and Duncan Snidal and Kenneth W. Abbot (1998) provide various reasons why states act and cooperate with formal institutions: firstly to advance policies; secondly to advance national interests; thirdly to share risks and burdens; and finally to advance certain values. EU-UN cooperation could be explained in terms of a shared value system that both actors seek to advance, and the normative and social legitimacy that the UN confers. However, these explanations do not go far towards understanding a complex process, involving dynamics that escape analyses about cooperation between the UN and regional organisations.

If $\mathrm{EU}$ conflict management tools, mandated or not by the $\mathrm{UN}$, should be taken for granted for an actor that is as atypical as the EU, African conflict management represents a new specialisation. Certainly, the EU argues cooperation with the $\mathrm{UN}$ in terms of the normative provisions. 


\section{Alfredo Tjiurimo Hengari}

In part II, dealing mainly with the Strategic Objectives, the European Security Strategy (ESS) highlights effective multilateralism as one of its strategic objectives, with the UN being a key and validating partner. It underlines its relationship with the United Nations in the following manner:

The EU should support the United Nations as it responds to threats to international peace and security. The EU is committed to reinforcing its cooperation with the $\mathrm{UN}$ to assist countries emerging from conflicts, and to enhancing its support for the UN in shortterm crisis management situations (European Union 2003:7).

Outside the formal framework and rhetoric about Africa as a security consumer, the presence of the EU in African conflicts can also be explained historically. This history explains the transformation of the EU identity in Africa, including its perception of threats and of how to deal with them. In addition to historical factors, the new geopolitical climate in Africa with international actors such as China and the US as well as other emerging middle power countries playing a more prominent role also provides an explanation for a more robust and UN-validated role in African conflicts (Franke 2007; International Crisis Group 2009). As a consequence, through the social construction of Africa as a problem, Africa is seen as a European problem.

The choice of cooperation on the part of the EU and the $\mathrm{UN}$ is a result of the African environment and the limits of national and international policies in dealing effectively with African conflicts. Cooperating and acting in concert is therefore seen as a positive development for both the EU and the UN. This is particularly so because Africa is the continent that is most affected by conflict. The factors explaining European interest in dealing with conflict in Africa, and by extension those of France and the UK are rather varied - both moral and material. Spatial, political and historical arguments explain the specificities of the EU and its quest for deeper institutionalisation with the UN in Africa. It is Africa where the majority of conflicts occur. In 2009, over twenty African countries were affected by armed conflict. Out of 14 peacekeeping operations under the UN DPKO, Africa has the highest concentration with six out of the 


\section{EU-UN partnership in military conflict management}

total 14. The UN deployments to Africa increased by 445 per cent over the past decade, while force generation problems and capacity constraints continued to affect these operations (Soder 2010). For a problem to become a foreign policy problem, it must be stated and framed in those terms.

Africa is a European Foreign Policy problem because European states framed the continent within a European security mindset. Bruno Charbonneau (2009:551) reinforces this point when he argues: 'Within this mindset, it is better to "transfer" or bring security into the space of insecurity than to have security "escape" into the space of security'. Two issues arise out of framing Africa in a manner in which Africa becomes a recipient of EU preferences and not necessarily an active framer of its own security needs. First, the development of EU tools in Africa do not point to a linear process, at least in the initial phases, but rather to improvisation and reflex reactions by default as a result of member states' preferences. Constructing a partnership with the UN implies a framework largely driven by national requirements. This could prove problematic in the long run when national requirements are projected as EU requirements and these are framed within a UN multilateral framework.

Second, the relationship seems to have been driven by the demand side on the part of the UN, stemming from the latter's capacity constraints. However, evolving notions of security within the EU have also driven it. The EU strategy attaches particular importance to the conflicts in Africa as an extension of its own security. The development of the ESDP and the African problem logically led the EU to revisit its relationship with the UN, both as a legitimising body and as the main peacekeeping implementer. The convergence of these two mutually reinforcing trends has led to an institutional rapprochement in line with the Brahimi report and resulting processes.

The EU security and coordination roles are carried on the basis of what the African environment generates in terms of conflict, including the consequences of such on Europe. It is why the EUSS argues that Africa as a potential source of instability in Europe. This implies that the EU becomes, out of necessity and for survival, a security actor in African conflicts. This is not only because Africa 


\section{Alfredo Tjiurimo Hengari}

needs security, but also because Europe can safeguard its security by providing security in Africa. The EU quest for normative legitimacy through the UN in African conflicts, therefore, seeks to explain itself in terms of what the EU represents as a global actor - an actor who is in favour of peace in the world, and is willing to take the challenge of providing peace in its own neighbourhood by acting in far-away places. Therefore, institutionalising its relationship with the $\mathrm{UN}$, as well as maintaining its involvement in African conflicts represents a form of continuity of what the EU actually is.

This position is informed by the hierarchical and perhaps instrumental perspective that the EU has of the UN in matters of peace and security. Such awareness, informed by the EU's understanding of the limits of the UN when it comes to peace operations, has had important implications for the EU vision in African conflicts. However, it shows that the EU-UN relationship as a response to African conflicts is constructed in a manner that is strategic, but at the same time imprecise and based on improvisation. In such framing, coordination is therefore logical in order to ensure greater coherence and efficiency.

\section{A logical relationship deserving coordination in Africa}

Increasing cooperation is part of a new panoply of developing narratives (at times competing) in the African conflict environment, including the AU-UN need for coordination and the difficulties inherent in such efforts (Bergholm 2008). However, the EU-UN relationship is largely un-problematised because it is viewed as both logical and functional since it offers the most promising perspectives of cooperation at both the military and civilian levels - areas in which the EU has developed savoir-faire in terms of capabilities and abilities to deploy forces within a short period of time. It is also seen as an operational relationship driven by UN requirements. Structurally, the UN faces shortages in troops, but above all there are deficiencies in rapid reaction capacity and in what it calls 'enabling assets', such as movement control, intelligence, medical units or logistics, which are less available than infantry battalions.

The UN counts more people in its peacekeeping operations than there are in all regional and sub-regional organisations together. In light of this permanent 
overstretch, especially since the late 1990s, including doubts about its capacity to deal with these demands, the UN encouraged a variety of actors to conduct military operations, and justified these with references to maintaining international peace and security. A high level of deployment since the end of the Cold War, combined with the increasingly complex nature of post-Cold War missions, pushed the limits of the UN's operational capacity. These limits and the African space demand for peace operations or security tout court are outlined in the discourse of both the EU and the UN as structuring the necessity for cooperation. This is why the UN Secretariat recurrently calls on the EU and its member states to provide such resources, and welcomes any EU initiative that strengthens the UN capacity directly or indirectly.

For the EU, coordination also offers interesting perspectives to construct and deepen ESDP tools, including capacities to act in conflict management situations. Certainly, the multiplicity of actors was a welcome development. But it has in turn intensified concerns about what tools to deploy in conflict situations and how. It has also put into perspective multiple chains of command. While the UN may view the EU as a security actor, which the UN can call upon in African conflicts, the internal dynamics of the ESDP highlights a contrasting picture in which deployment is based on the preferences of member states.

The development of the EU crisis management tools has come a long way since Maastricht, a way which has included the Franco-British Saint Malo summit. However, the available EU tools in military crisis management are not independent of the preferences of member states, in particular France and the UK. These states therefore challenge existing perceptions of the EU as a privileged and indifferent institution in the formulation of $\mathrm{UN}$ responses to crises in Africa. Similarly, there has been concern within the UN that the whole security identity of the EU appears to develop to the detriment of the UN's inclusive approach as well as of UN peacekeeping needs (Tardy 2005). Importantly, it is likely to develop at the expense of Africa's security infrastructure because such a process is by and large an extension and validation of French and British preferences in conflict management. 


\section{A relationship delaying the development of Africa's nascent security infrastructure}

Chronic instability and the conflicts in African countries explain and justify materially and perhaps morally the international interventions. While logical, the consolidation of EU-UN cooperation in African conflicts occurs at a time when Africa has demonstrated a proactive willingness to give credence to the slogan of African solutions to African problems. This slogan received support within the UN system, including major powers such as France and the UK whose long involvement with Africa has also been one of intervention as, among others, the cases of Côte d'Ivoire and Sierra Leone respectively suggest. If the EU provided substantive support to the consolidation of Africa's security infrastructure, the involvement of member states through bilateral initiatives could potentially undermine the consolidation of Africa's own initiatives. Without doubt there is widespread acceptance of normative frameworks and the setting up of institutional mechanisms to solve conflicts in Africa and to defer certain security matters to the AU and its regional organisations. These have found empirical expression in the form of AU-UN-led conflict management operations in Africa, such as UNAMID in Darfur in July 2007, or the first AU-led African Mission in Burundi (AMIB) in 2003.

EU-UN cooperation, therefore, becomes self-evident in a situation in which Africa is seen to emerge as the biggest beneficiary of such cooperation. What is problematic, however, is that implementing this type of cooperation is produced and reproduced with no input from African actors. This is not only the result of the absence of vast Africa-specific knowledge in the domain, but the little that is there is hardly considered. The above-mentioned awareness is not only a consequence of hierarchical claims on the part of the EU regarding its capacity to act as opposed to the UN incapacity to act efficiently, but it is a view that is also normatively advanced by the UN.

To reaffirm the above-mentioned view, the former UN Secretary-General, Kofi Annan (2005), noted that in grave crisis situations the UN is not the most suitable instrument to act. He had insisted on the importance of the deployment of multinational forces under the leadership of 'lead nations' or 
'framework nations'. This type of socialisation in terms of language, including the institutionalisation of such discourses through the EU-UN relationship, allow for the political legitimisation of the EU as a security actor outside its immediate perimeters. The extension of such also allows for such legitimacy to be grounded in international law. Understanding cooperation this way would reinforce the view about EU capacities as indispensable to the UN, while Africa is viewed as a liability and not an instinctive actor.

\section{Africa as a liability and not as an actor}

Constructing the conflict management agenda in Africa, including coordination with the UN, is therefore not without risks. Such risks are related to a possible new division of labour between 'poor peacekeeping' in Africa under the UN set-up and 'rich peacekeeping' in Europe under the EU. With the formalisation of the EU-UN relationship, including the operationalising of this relationship in Africa, the UN recurrently calls on the EU and its member states to provide such resources, and welcomes any EU initiative that strengthens the UN capacity directly or indirectly (Fréchette 2004).

The UN was also worried that the deepening of the EU crisis management tools could affect European contributions to the UN crisis management tools. Such a view was not misplaced as certain countries, including Ireland and Austria, had argued that their contributions to the EU conflict management framework would affect their contributions to UN conflict management. This in turn would affect Africa's needs for security adversely as it would expose military conflict management to the interests of the powerful European states. The construction of the EU as another avenue through which the UN can act in African conflicts has potentially created possibilities for the instrumentalisation of the EU to advance the interests of powerful states in the Security Council, in particular those of France. On the one hand, the EU and its member states are strong supporters of the UN, both in accordance with the ESS and the concept of 'effective multilateralism' (Eide 2004). On the other hand, when actors construct capacities, the objective is to act more efficiently with acquired capacities. However, the factors explaining why the EU (through the UN) opted to get 


\section{Alfredo Tjiurimo Hengari}

involved in African conflicts are not the consequence of the construction of social reality, but are also based on the deepening of certain values and identities.

As we had argued, the case of EU interest in Africa points to an interaction between geography as an external environment and conflicts as a socially constructed reality. Concerns about the whole ESDP process developing to the detriment of the UN's inclusive approach as well as of UN needs with regard to conflict management tools are therefore not misplaced. So are concerns about the consequences of this mode of subcontracting on the development of Africa's own security infrastructure. Thierry Tardy (2005:49) argues that EU support for the UN is guided largely by the EU's objectives to become a global security actor, to generate visibility for itself and to keep control of autonomy over decision making. An analysis of the deployment of EU tools in African conflicts confirms this trend.

While requests for EU-led operations in Africa had originated from the UN, notably from the French-led DPKO, the EU were always able to frame the terms of its engagement within the African environment in terms of its own capabilities and needs. In doing so, it has been able to control the means and ends of its involvement in African conflicts. The baseline of the EU operations in African conflicts shows that the lead states, notably France, was instrumental in the construction of such operations. The salience of the EU agenda is therefore evident and far greater in EU-UN cooperation as opposed to the salience of the UN or African agenda. Analysis of this relationship should therefore move beyond institutional concerns about EU-UN effectiveness in African conflicts, as Claudia Major (2008) would insist with regard to broader questions about the place of Africa's security infrastructure. It is therefore questionable how EU-UN cooperation, underpinned by the EU search for a profile. could substantively be reconciled with the consolidation of Africa's security infrastructure to deal with its own conflicts.

\section{Conclusions}

An attempt had been made to avoid framing the EU-UN institutional relationship and rapprochement in African conflicts independently of the power hierarchies 


\section{EU-UN partnership in military conflict management}

within the UN, notably the UNSC with two permanent members France and the UK being leading members of the EU. Similarly, we have cautioned that such cooperation should not be analysed independently of the interaction between the national foreign policies of France and the UK, both from a bilateral perspective, including how they codify and modify the capacity of the EU to act in African conflicts. Better policies and greater coherence, including efficiency, are certainly welcome in the African conflict management environment. However, such a problem-solving but uncritical stance rooted in EU-salience, promising better, also denies the structural changes that ought to take place for Africa to consolidate its conflict management architecture. It does so by not questioning the power hierarchies underlying the EU-UN relationship with Africa. The narrative about the conflict management infrastructure is therefore a result of the power underside driven by EU requirements, while the UN's role is one of validation on the basis of the EU's implicit power and normative claims. The UN-EU cooperation could end up being a means to re-authorise and legitimise French and British interests, including EU policy in Africa without Africa's own security infrastructure making the necessary leaps it ought to make.

Africa is therefore not only a field that facilitates cooperation between the EU and the $\mathrm{UN}$ - it is also an empirical terrain for the validation of institutionalised policies, initiated within members states of the EU, but adapted and projected into the EU. If a lot is said of the value of EU-UN cooperation in African conflicts, there are also competing and contradicting tools and objectives that these actors bring into the African conflict management environment, potentially undermining Africa's own security infrastructure.

\section{Sources}

Annan, Kofi 2005. Implementation of the UN Millennium Declaration. Report of the Secretary General 58/328, United Nations.

Bellamy, J.M., P. Williams and S. Griffin 2004. Understanding peacekeeping. Cambridge, Polity.

Bergholm, Linnea 2008. The UN and the AU: A co-dependent relationship on matters of peace and security. In: Dag Hammarskjöld Foundation The United Nations, Security and Peacekeeping in Africa. Lessons and Prospects. Critical Currents 5. Uppsala, Dag Hammarskjöld Foundation. pp. 23-39. 


\section{Alfredo Tjiurimo Hengari}

Charbonneau, Bruno 2009. What is so special about the European Union? EU-UN cooperation in crisis management in Africa. International Peacekeeping, 16 (4), pp. 546-561.

Council of the European Union 2001. Conclusions of the Presidency, European Council, Göteborg 15 and 16 June 2001, Section V, Peace and Security Cooperation. Available from: <http://www.consilium.europa.eu/uedocs/cms_data/docs/pressdata/fr/ec/00200-r1. f1.pdf $>$ [Accessed January 2011].

Council of the European Union 2003. Joint Declaration on UN-EU cooperation in crisis management, September, New York.

Council of the European Union 2004. EU-UN cooperation in Military Crisis Management Operations: Elements of implementation of the EU-UN Joint Declaration, 17-18 June 2004. Available from: <http://www.consilium.eu.int/uedocs > [Accessed 3 February 2011].

Eide, E.B. ed. 2004. Effective multilateralism: Europe, regional security and a revitalised UN. London, The Foreign Policy Centre/Global Europe Publications.

European Commission 2003. The EU and the UN: The choice of multilateralism, Communication from the European Commission, September, Brussels.

European Union 2003. European Security Strategy: A secure Europe in a better world. Available from: <http://www.consilium.europa.eu/uedocs/cmsUpload/78367.pdf> [Accessed 13 February 2007].

Foot, Rosemary, Michael Mastanduno and S. Neil MacFarlane 2003. US hegemony and international organizations. Oxford, Oxford University Press.

Franke, B. 2007. Enabling a continent to help itself: U.S. military capacity building and Africa's emerging security architecture. Zürich, Center for Contemporary Conflict.

Fréchette, L. 2004. Speech by the UN Deputy Secretary-General before the European Parliament, Strasbourg.

Gégout, Cathérine 2002. The French and British change in position in the CESDP: A security community and historical institutionalist perspective. Politique européenne, 8, pp. 62-87.

Ginsberg, Roy 2001. The European Union in world politics: Boulder, Rowman and Littlefield.

Hengari, A. Tjiurimo 2006. L'Europe et la construction d'une politique franco-britannique sur la gestion des crises en Afrique Subsaharienne, Memoire de DEA, Centre de Documentation du Département de Science Politique, Université Paris I PanthéonSorbonne.

International Crisis Group 2009. China's growing role in UN peacekeeping. International Crisis Group, Asia Report, No 166, 17. pp. 1-43.

Jonah, J.O.C. 2004. The United Nations. In: Adebayo, Adekeye and Ismail Rashid eds. West Africa's security challenges: Building peace in a troubled region. London, Lynne Rienner.

Keohane, Robert 2006. The contingent legitimacy of multilateralism. Garnet Working Paper, 9, pp. 1-24. 


\section{EU-UN partnership in military conflict management}

Mace, C. 2003. Opération Artémis: Mission improbable. European Security Review, 8, pp. 221-237.

Major, Claudia 2008. EU-UN cooperation in military crisis management: The experience of EUFOR RD Congo in 2006. Occasional Paper 72. Paris, Institute for Strategic Studies.

Permanent Mission of Sweden to the UN 2001. 2001: Final report, Swedish Presidency of the European Union. Available from: <http://www.un.int/sweden/pages/eu/state_eu/final\%20 report\%202001.htm> [Accessed 7 February 2011].

Snidal, Duncan and Kenneth W. Abbot 1998. Why states act through formal international organizations, Journal of Conflict Resolution, 42 (1), pp. 3-32.

Soder, Kirsten 2010. Multilateral peace operations. Stockholm, Stockholm International Peace Research Institute (SIPRI). SIPRI Fact Sheet.

Soeterdorp, Ben 1999. Foreign policy in the European Union: Theory, history and practice. London, Longman.

Tardy, Thierry 2005. EU-UN cooperation in peacekeeping: A promising relationship in a constrained environment. In: Ortega, Martin ed. The EU and the UN - Partners in effective multilateralism. Chaillot Paper 78. Paris, EUISS, pp. 49-68.

United Nations 1945. Charter of the United Nations. New York, United Nations.

United Nations 2000. Report of the Panel on United Nations Peace Operations, A/85/305-S/2000/809. New York, United Nations. 